\title{
Pengaruh Pemberian Ekstrak Biji Tanaman Jarak Pagar (Jatropha Curcas. L) Terhadap Gambaran Histopatologi Hepar dan Kadar SGPT (Serum Glutamic Piruvic Transaminase) pada Tikus (Rattus norvergicus)
}

\author{
Effect of Jatropha(Jatropha curcas L.) Seeds Extract Induction on Liver Histopathology and \\ SGPT levels (Serum Glutamic Piruvic Transaminase) on Rat (Rattus norvegicus)
}

\author{
Neny Fitria ${ }^{1}$, Herlina Pratiwi ${ }^{2 *}$, Edwin Widodo ${ }^{3}$, Angelia Primajayanti ${ }^{1}$, Novia Dwi Anggraini ${ }^{1}$, \\ Nurfitriani $^{1}$, Nadia Findi ${ }^{1}$ \\ ${ }^{1}$ Mahasiswa Fakultas Kedokteran Hewan Universitas Brawijaya Malang \\ ${ }^{2}$ Laboratorium Embriologi Fakultas Kedokteran Hewan Universitas Brawijaya Malang \\ ${ }^{3}$ Laboratorium Faal Fakultas Kedokteran Brawijaya Malang \\ *Email : herlinapratiwi.drh@ub.ac.id
}

\begin{abstract}
ABSTRAK
Jarak Pagar atau Jatropha curcas L merupakan tanaman famili Eurphobiaceae dengan kegunaan secara medis dan non medis, diantaranya yaitu sebagai kontrasepsi oral. Bagian Jarak Pagar yang sering dimanfaatkan adalah bagian biji. Namun, Jarak Pagar juga mengandung saponin, phorbol ester, kursin, tanin yang dapat menyebabkan keracunan organ. Penelitian ini dilakukan untuk mengetahui pengaruh ekstrak biji Jarak Pagar terhadap histopatologi hati dan kadar SGPT tikus Rattus Norvegicus, dengan menggunakan metode Rancangan Acak Lengkap. Hewan coba dibagi dalam 4 kelompok, setiap kelompok terdiri dari 5 ekor tikus betina. Kelompok tersebut yaitu kelompok kontrol tanpa perlakuan dan kelompok perlakuan per oral ekstrak biji Jarak Pagar pada dosis 10, 50, dan $100 \mathrm{mg} / \mathrm{kg}$ BB. Proses induksi dilakukan setiap hari selama 14 hari, pada hari ke-15 dilakukan nekropsi. Organ hati diambil untuk analisis histologi dan sampel darah diambil untuk mengukur kadar SGPT. Hasil penelitian menunjukkan bahwa pemberian ekstrak biji Jarak Pagar dapat meningkatkan kadar SGPT. Pemberian ekstrak biji Jarak Pagar pada dosis $100 \mathrm{mg} / \mathrm{kg}$ berat badan menginduksi kerusakan hepatosit paling parah di antara kelompok perlakuan.
\end{abstract}

Kata Kunci : hepatotoksik, histopatologi hati, jarak pagar, SGPT

\begin{abstract}
Jatropha or Jatropha curcas L. is a plant of the Euphorbiaceae family with medicinal and non-medical uses, including oral contraceptives. The part of Jatropha that is often used is the seed. However, Jatropha seed also contains saponins, phorbol esters, currants, tannins which can cause organ poisoning. This study was conducted to determine the effect of Jatropha seed extract on liver histopathology and SGPT levels in Rattus Norvegicus rats, using a completely randomized design method. Experimental animals were divided into four groups, and each group consisted of five female rats. The groups were the control group without treatment and those treated with Jatropha seed extract orally at doses of 10,50 , and $100 \mathrm{mg} / \mathrm{kg}$ BW. The induction process was carried out every day for 14 days, on the 15 th day, a necropsy was performed. Livers were taken for histological analysis, and blood samples were taken to measure SGPT levels. Results showed that the administration of Jatropha seed extract could increase SGPT levels. The administration of Jatropha seed extract at a dose of $100 \mathrm{mg} / \mathrm{kg}$ body weight induced the most severe damage of hepatocytes among the treatment groups.
\end{abstract}

Keywords : hepatotoxic, jatropha curcas, liver histopathology, SGPT

Website : http://vbcj.ub.ac.id

E-mail :vbcj@ub.ac.id 
Fitria dkk. : Pengaruh Pemberian Ekstrak Biji Tanaman Jarak Pagar (Jatropha Curcas. L) Terhadap Gambaran Histopatologi Hepar dan Kadar SGPT (Serum Glutamic Piruvic Transaminase) pada Tikus (Rattus norvergicus)

\section{PENDAHULUAN}

Jarak Pagar berasal dari daerah tropis yang merupakan tanaman semak. Tanaman ini masuk dalam famili Euphorbiaceae. Tanaman Jarak Pagar disebut juga Jatropha curcas. Tanaman Jarak Pagar mulai ditemukan di Indonesia pada masa penjajahan Jepang dan menyebar cukup luas dalam waktu singkat, terutama pada daerah Jawa yaitu Jawa Tengah dan Timur (Nurcholis dan Sumarsih, 2007). Tanaman Jarak Pagar bukan tanaman yang berasal dari Indonesia. Setiap bagian dari Jarak Pagar memiliki manfaat secara medis, termasuk pada bagian biji. Menurut (Sudradjat et al., 2006), biji Jarak Pagar memiliki kandungan protein, lipid, dan karbohidrat yang cukup tinggi. Zat aktif seperti saponin, alkaloid, curcin, lectin, isoviteksin, terpenoid, flavonoid, viteksin, dan phorbol ester juga terkandung dalam biji Jarak Pagar. Zat aktif ini memiliki fungsi sebagai obat medis tradisional yaitu anti-tumor, anti-fertilitas, dan antiinflamasi. Survei yang dilakukan oleh Pokharkar et al., (2010) di India menunjukkan bahwa buah dan biji Jarak Pagar memiliki aktivitas anti-fertilitas. Sejalan dengan Pokharkar et al., (2010), penelitian yang dilakukan (Ahirwar dan Kharya, 2010) juga menunjukkan aktivitas anti-fertilitas pada tikus betina yang mendapatkan ekstrak etanol dari biji Jarak Pagar secara oral.

Penggunaannya secara tradisional memiliki kelebihan dan kekurangan. Kelebihan menggunakan tanaman ini adalah karena ketersediaannya, mudah dibudidayakan, murah dan efektif.
Kekurangannya adalah terdapat efek racun bagi tubuh. Senyawa racun dalam tanaman Jarak Pagar banyak ditemukan dalam bagian biji, diantaranya saponin. Saponin dapat menyebabkan turunnya tegangan permukaan, yang berujung pada rusaknya membran sel. Ikatan antara saponin dan fosfolipid yang merupakan senyawa penyusun membran sel menyebabkan gangguan pada permeabilitas membran sel, sehingga akan menyebabkan kerusakan organ, salah satunya hepar. Gangguan pada sel hepar dapat diidentifikasi dengan mengamati kerusakan histopatologi hepar dan tingginya kadar enzim SGPT (Serum Glutamic Piruvyc Transaminase) dari hewan.

Penelitian ini bertujuan mengetahui pengaruh pemberian biji Jarak Pagar terhadap gambaran histopatologi hepar dan kadar SGPT darah Rattus norvegicus.

\section{MATERI DAN METODE}

\section{Alat dan Bahan}

Biji Jarak Pagar kering yang diperoleh dari buah Jarak yang matang, tikus Rattus norvegicus betina, pellet, air minum, kandang tikus, sonde, blender, gelas ukur, ayakan, dissecting set, alkohol $(70 \%$, $80 \%$, 96\%), etanol (70\% dan 95\%), Phosphat Buffer Saline (PBS), PFA atau Paraformaldehyde $10 \%$, parafin, mikrotom, larutan Hematoxylin-Eosin, larutan xylol, object glass, cover glass, tabung venoject warna ungu, spuit $1 \mathrm{~mL}$, sampel darah, papan bedah, formalin $10 \%$, timbangan, mikroskop dan kulkas merupakan alat dan bahan yang digunakan untuk penelitian. 
Fitria dkk. : Pengaruh Pemberian Ekstrak Biji Tanaman Jarak Pagar (Jatropha Curcas. L) Terhadap Gambaran Histopatologi Hepar dan Kadar SGPT (Serum Glutamic Piruvic Transaminase) pada Tikus (Rattus norvergicus)

\section{Ekstraksi Biji Jarak Pagar}

Penelitian ini menggunakan biji Jarak Pagar dari buah yang sudah matang dan kering. Biji Jarak Pagar tersebut dirajang kemudian dihaluskan lalu diayak sehingga membentuk serbuk lalu disimpan dalam wadah yang kering dan tertutup rapat.

Serbuk biji Jarak Pagar di maserasi dengan pelarut etanol $70 \%$ dengan perbandingan 1 : 3 . Hasil maserasi kemudian disaring, filtrat dipekatkan dengan penguap putar hingga dihasilkan ekstrak berupa cairan kental (Nurhadijah et al., 2018)

\section{Rancangan Penelitian}

Kelompok 1 yaitu tanpa perlakuan, sebanyak lima ekor tikus disondekan per oral air minum $1 \mathrm{~mL}$. Kelompok II, lima ekor tikus diberikan suspensi ekstrak biji Jarak Pagar dengan dosis $10 \mathrm{mg} / \mathrm{kgBB}$. Kelompok III, lima ekor tikus diberi suspensi ekstrak biji Jarak Pagar 50 mg/kgBB. Kelompok IV, lima ekor tikus diberi suspensi ekstrak biji Jarak Pagar $100 \mathrm{mg} / \mathrm{kgBB}$. Pakan dan minum diberikan secara adlibitum. Induksi dilakukan dua kali sehari secara per oral selama 14 hari.

\section{Euthanasia dan Preparasi Organ Hepar Serta Pengambilan Darah}

Euthanasia, pengambilan organ hepar dan pengambilan darah pada hewan dilakukan pada hari ke-15. Pengambilan sampel darah dilakukan secara intracardial. Sampel darah selanjutnya disentrifus pada kecepatan $3.000 \mathrm{rpm}$ selama 10 menit untuk mendapatkan serum. Organ hepar dimasukkan ke dalam pot sampel yang telah berisi PBS (Arjadi et al., 2017). Analisis histopatologi hepar dan kadar SGPT dilakukan di laboratorium Histologi Fakultas Kedokteran Hewan Universitas Brawijaya (FKH UB).

\section{Pembuatan Preparat Histopatologi Hepar}

Preparasi histopatologi meliputi fiksasi, dehidarsi, clearing, filtrasi, paraffin embedding, trimming dan pewarnaan. Fiksasi organ dilakukan menggunakan PFA $10 \%$ yang dimasukkan ke dalam wadah tabung plastik kecil. Selanjutnya organ diperlakukan dengan dehidrasi alkohol bertingkat. Mulai dari konsentrasi 50\% (24 jam), 2 jam dengan etanol 70\%, dan selama 20 menit dengan etanol yang berkadar $80 \%$, 95\% dan absolut. Lalu clearing menggunakan xylol I (20 menit) dan 30 menit dengan xylol II. Selanjutnya dilakukan infiltrasi serta embedding dengan menggunakan parafin cair (suhu inkubasi $58-60^{\circ} \mathrm{C}$ ). Kemudian dilakukan proses trimming dengan ketebalan $\pm 5 \mu \mathrm{m}$. Potongan tersebut diletakkan di atas permukaan air waterbath bersuhu $46^{\circ} \mathrm{C}$. Bentuk irisan dirapikan, diletakkan pada object glass yang telah diolesi entellan dan dilakukan pewarnaan HaematoxylinEosin (HE). Preparat hepar kemudian diamati menggunakan mikroskop cahaya perbesaran 400x. 
Fitria dkk. : Pengaruh Pemberian Ekstrak Biji Tanaman Jarak Pagar (Jatropha Curcas. L) Terhadap Gambaran Histopatologi Hepar dan Kadar SGPT (Serum Glutamic Piruvic Transaminase) pada Tikus (Rattus norvergicus)

\section{Analisis Data}

Pengolahan data yang dilakukan pada variabel histopatologi hepar adalah secara deskriptif, sedangkan pada kadar SGPT diolah dengan One Way ANOVA pada taraf kepercayaan 95\%. Uji lanjutan dikerjakan menggunakan uji Tukey. Analisis statistik dikerjakan dalam SPSS 21 (IBM, CA, USA).

\section{HASIL DAN PEMBAHASAN}

\section{SGPT}

Hasil uji statistik kadar SGPT dalam darah tikus uji tersaji dalam Tabel 1. Analisis statistik menggunakan ANOVA memperlihatkan bahwa adanya pengaruh yang berbeda nyata pada tikus putih yang diberi suspensi ekstrak biji Jarak Pagar pada dosis berbeda (Tabel 1). Analisis lanjutan menggunakan uji Tukey didapatkan hasil bahwa rata-rata kadar SGPT pada kelompok kontrol menunjukkan perbedaan yang nyata dengan semua kelompok perlakuan. Ratarata kadar SGPT pada kelompok kontrol sebesar 24 U/L. Menurut Agung (2015), kadar SGPT tikus yang normal adalah 17,5-30,2 U/L.

Riset ini menunjukkan bahwa pemberian ekstrak etanol dari biji Jarak Pagar mampu meningkatkan kadar SGPT. Peningkatan kadar SGPT di dalam darah ini mungkin disebabkan karena tingginya jumlah saponin yang masuk dalam tubuh dan mengakibatkan terjadi kerusakan hepatosit. Menurut Wahyuningtyas et al. (2018), saponin dapat mengakibatkan naiknya permeabilitas sel dan menurunkan tegangan permukaan sehingga mengakibatkan kebocoran sel. Hepatosit akan pecah sehingga cairan intraseluler keluar dan enzim SGPT akan masuk dalam sistem peredaran darah sehingga mengakibatkan peningkatan kadar SGPT dalam darah (Suryaningsih et al., 2017).

Tabel 1. Kadar Serum Glutamic Piruvyc Transaminase (SGPT) dalam darah tikus yang diberikan suspensi dari ekstraki biji Jarak Pagar

\begin{tabular}{cc}
\hline & $\begin{array}{c}\text { Nilai Rata-rata } \\
\text { Kelompok Perlakuan } \\
\text { Kadar SGPT (U/L) } \pm \\
\text { SD }\end{array}$ \\
\hline P1 (10 mg/kgBB) & $24 \pm 1,581^{\mathrm{a}}$ \\
P2 (50 mg/kgBB) & $39,2 \pm 1,923^{\mathrm{b}}$ \\
P3 (100 mg/kgBB) & $62 \pm 2,549^{\mathrm{c}}$ \\
\hline Keterangan: Angka dengan notasi (a, b, c, d) & $115 \pm 3,807^{\mathrm{d}}$ \\
berbeda maka menunjukkan bahwa & terdapat perbedaan signifikan antar \\
kelompok (p<0,05)
\end{tabular}

\section{Histopatologi Hepar}

Gambar 1 menunjukkan bahwa histopatologi dari organ hepar tikus pada kelompok kontrol dan perlakuan. Gambaran histopatologi hepar tikus kelompok kontrol (P0) memiliki sel hepar normal dengan dua komponen utama yaitu hepatosit dan sinusoid. Gambaran jaringan dalam organ hepar normal berupa hepatosis dengan satu inti ditengah, sel berbentuk polygonal dan ruang sinusoid yang berbentuk irregular (Pratiwi et al., 2016).

Gambaran histopatologi P1, yaitu kelompok tikus dengan perlakuan esktrak biji Jarak Pagar dosis $10 \mathrm{mg} / \mathrm{kgBB}$ selama 14 hari, menunjukkan perubahan hepatosis yang tidak terlalu banyak. Mayoritas hepatosis masih memiliki struktur dan batas sel yang jelas, hanya di beberapa lapang pandang ditemui 
Fitria dkk. : Pengaruh Pemberian Ekstrak Biji Tanaman Jarak Pagar (Jatropha Curcas. L) Terhadap Gambaran Histopatologi Hepar dan Kadar SGPT (Serum Glutamic Piruvic Transaminase) pada Tikus (Rattus norvergicus)

hepatosis dengan kondisi piknosis yang ditandai adanya inti sel hepar terlihat menyusut.

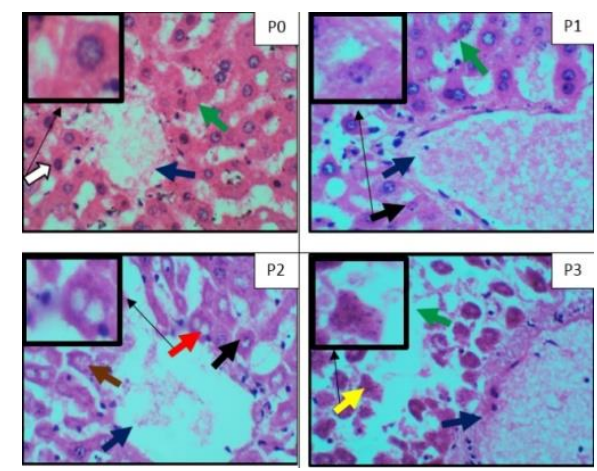

Gambar 1. Histopatologi hepar P0, P1, P2, P3

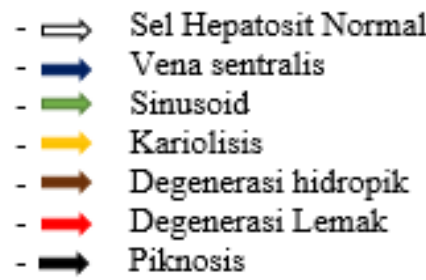

Gambaran histopatologi hepar tikus kelompok perlakuan P2 yaitu kelompok perlakuan dengan $50 \mathrm{mg}$ esktrak biji Jarak Pagar per kg BB selama 14 hari, menunjukkan adanya perubahan struktur hepatosis pada hepar tikus yang ditandai dengan terjadinya piknosis dan degenerasi sel seperti degenerasi hidropik dan lemak yang merupakan tanda kerusakan hepatosit yang bersifat reversible. Degenerasi hidropik menunjukkan adanya ruangan-ruangan jernih pada sitoplasma namun tidak sejernih kolagen atau lemak. Degenerasi hidropik muncul disebabkan oleh sel yang tidak mampu mempertahankan homeostatis ion dan cairan, sehingga fungsi pompa ion dalam membran sel hilang (Maulina, 2018). Degenerasi lemak yang terlihat pada gambaran histologi berupa vakuolisasi di mana hampir semua bagian hepatosit terisi butiran lemak.
Histopatologi hepar tikus pada kelompok perlakuan P3 yaitu tikus dengan pemberian ekstrak biji Jarak Pagar sebanyak $100 \mathrm{mg} / \mathrm{kgBB}$ selama 14 hari, terlihat bahwa kerusakan hepar pada satu lobulus lebih banyak jika dibandingkan dengan P2. Jumlah sel yang mengalami nekrosis dalam satu lobulus lebih banyak, struktur sel rusak, mengalami kariolisis, batas sel dan sinusoid tidak terlihat jelas serta sinusoid mengalami pelebaran. Menurut Jaka et al., (2014), melebarnya sinusoid terjadi karena adanya toksikan yang terjadi dalam sel hati yang rusak. Sel tersebut akan mudah berinteraksi dengan sinusoid, dan jika konsentrasi toksikan tinggi maka akan terjadi pelebaran sinusoid. Hasil yang diperoleh menunjukkan bahwa tingkat kerusakan paling tinggi terjadi pada kelompok perlakuan P3 yaitu terlihat hampir semua sel mengalami nekrosis. Kelompok P1 dan P2 memiliki tingkat kerusakan yang hampir sama meskipun tingkat kerusakan dalam satu lobulus tampak lebih ringan dibandingkan dengan pada kelompok P3.

\section{KESIMPULAN}

Pemberian ekstrak biji Jarak Pagar pada tikus mampu meningkatkan kadar SGPT pada serum darah Tikus dan menyebabkan kerusakan hepatosit.

\section{DAFTAR PUSTAKA}

Agung, M. 2015. Efek Pemberian Vitamin E terhadap Kadar SGPT dan SGOT Serum Darah Tikus Putih (Rattus Norvegicus) Jantan Galur Wistar yang Diberi Aktifitas Fisik. [Skripsi]. Semarang: Universitas Semarang. 
Fitria dkk. : Pengaruh Pemberian Ekstrak Biji Tanaman Jarak Pagar (Jatropha Curcas. L) Terhadap Gambaran Histopatologi Hepar dan Kadar SGPT (Serum Glutamic Piruvic Transaminase) pada Tikus (Rattus norvergicus)

Ahirwar, D dan Kharya, M.D. 2010. Effect of Ethanolic Extract of Jatropha curcas Seeds on Estrus Cycle of Female Albino Rats. Pharm. Lett. 2(5):146-150.

Arjadi, F., Dhadhang, W.K., Tomi, N., Fikriah, R.F., Emiliza, S., Nafisah, P.W. 2017. Pengaruh Pemberian Ekstrak Etanol Akar Purwoceng (Pimpinella pruatjan Molk) Secara Akut Terhadap Fungsi Hepar Tikus Putih (Rattus novergicus) Jantan : Uji Toksisitas Akut. Prosding Seminar Nasional.

Jaka, N.S., Rahayu, N.U., Isnaeni, W. 2014. Struktur Mikroanatomi Hati dan Kadar Kolesterol Total Plasma Darah Tikus Putih Strain Wistar Pasca Suplementasi Minyak Lemuru dan Minyak Sawit. FMIPA Universitas Negeri Semarang.

Maulina M. 2018. Zat-Zat Yang Mempengaruhi Histopatologi Hepar. Universitas Malikulsaleh Sulawesi. Unimal Press.

Nurcholis M, Sumarsih S. 2007. Jarak Pagar dan Pembuatan Biodiesel. Yogyakarta: KANISIUS.

Nurhadijah, L., Alfa, A.P., Widyawati, Ferian, A.S., Baiq, N.M., Isyani, T.D.T., Irma, H.S. 2018. Aktivasi Formulasi Biji Jarak Pagar dan Pare Terhadap Spermatogenesis pada Tikus Wistar. J. Jamu Indones. 3(1):26-31.

Pokharkar, R.D., Saraswat, R.K., Kotkar S. 2010. Survey of Plants Having Antifertility Activity From Western
Ghat Area of Maharashtra State. J. Herb. Med. Toxicol. 4(2):71-75.

Pratiwi, H., Winarso, D., Handoyo, N. 2016. Effect of Turmeric Etanol Extract (Curcuma Longa L) on Low Density Lipoprotein Level and Liver Histopathology Image in Type 1 Diabetes Mellitus Rat Model Induced by Streptozotocin. J. Ilmu Teknol. Dan Ternak. 11(1):1-7.

Sudradjat, R., Lussy, D.W., Setiawan. 2006. Detoksifikasi Dan Uji Toksisitas Akut Limbah Bungkil Biji Jarak Pagar Terhadap Tikus Putih. Jakarta: Penebar Swadaya.

Suryaningsih, N.M., Dewi, I.A.T., Suksmawati, N.K.A., Putri, N.P.R.A., Febrianti, N.M., Warditiani, N.K. 2017. Pengaruh Kadar SGOT SGPT dan Morfologi Hepar Tikus Putih Betina Wistar Pada Pemberian Isolat Andrografolid. J. Farm. Udayana::34-38.

Wahyuningtyas, P., Janika, A.S., Muflichatun, S.M. 2018. Hepatosomatic Index (HSI) dan Diameter Hepatosit Mencit Setelah Paparan Ekstrak Air Biji Pepaya. Laboratorium Biologi Struktur dan Fungsi Hewan: Universitas Diponegoro Semarang. 